\title{
PRODUCTION OF BIOACTIVE COMPOUNDS BY DIFFERENT FUNGAL SPECIES
}

\author{
ANTÓNIA JEKKEL and M. SZEGEDI
}

Institute for Drug Research Ltd., Budapest and Richter Gedeon Ltd, Budapest, Hungary

\section{Production of cholesterol-lowering drugs}

Nowadays in Hungary and all over the world there is an increasing demand on cholesterol-lowering drugs. Highest risk factor of atherosclerosis and especially coronary occlusion is the high cholesterol level of the plasma. In the recent two decades the 3-hydroxy-3-methylglutaryl coenzyme A reductase (EC.1.1.1.34) as the rate limiting key enzyme of the cholesterol biosynthesis in the organism was extensively examined. Mevinolin and other related compounds (compactin, pravastatin, simvastatin) are the competitive inhibitors of the HMG-CoA reductase enzyme. Our investigations were focussed on finding microorganisms, which would produce HMG-CoA reductase enzyme inhibitors. During screening, covering about 20,000 fungus strains two microorganisms were selected, one of them an Aspergillus species was able to biosynthesize mevinolin and another strain belongs to the Penicillium genus was able to produce compactin. In the course of our experiments new, economic microbial processes were developed for both cholesterol-lowering agents.

ANTÓNIA JEKKEL

Institute for Drug Research

P.O. Box 82, H-1325 Budapest, Hungary

MIHÁLy SZEGEDI

Richter Gedeon Ltd.

P.O. Box 27, H-1475 Budapest, Hungary 
<smiles>CC1C=CC2=C[C@H](C)C[C@H](OC(=O)C(C)(C)[13CH3])[C@@H]2C1CC[C@@H]1CC(O)CC(=O)O1</smiles>

Lovastatin

(MK-803, Mevinolin, MEVACOR)

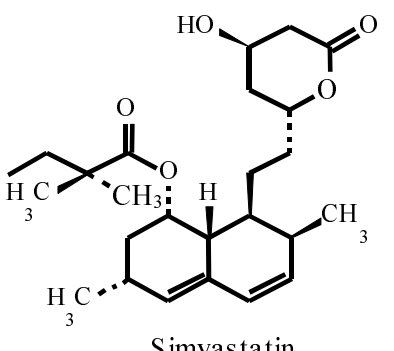

Simvastatin

(MK-733, Synvinolin, ZOCOR)<smiles>CCC(C)C(=O)O[C@H]1CCC=C2C=CC(C)C(CC[C@@H]3CC(O)CC(=O)O3)C21</smiles>

Mevastatin

(ML-236B, CS-500, Compactin)

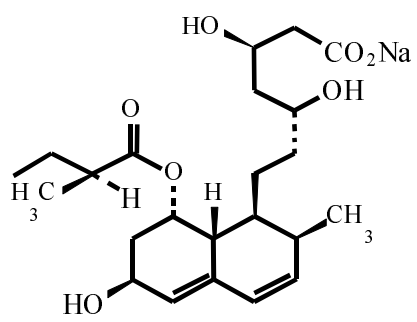

Pravastatin

(CS-514, SQ-31000, Eptastatin)

\section{Production of ergot alkaloids}

Ergot is the sclerotial form of parasitic fungi of the genus Claviceps growing on wild grasses and cereals. The ergot alkaloids are the secondary metabolites of these fungi.

Claviceps purpurea was responsible for the deaths of thousands of people in Middle Ages, in France and Germany which were the rye-bread eating region of Europe but in the 20th century it has become the source of potent medicines per se, and many of their semisynthetic derivates.

The life cycle of Claviceps in nature is complex. It consists of an asexual and a sexual phase.

The first consists of a filamentous mycelium that reproduces through conidia. The second starts with formation of a sclerotium. The sclerotium can be considered as the early stage of sexual differentiation of the fungi. In the spring the ergot, while surviving in the soil, has become activated by frost and it germinates with stalked stromata. In the round head of stromata the perithecias can be found in which the asci and the ascospores are visible. The thread-like ascospores infect the flower of rye or host plant.

In nature, ergot alkaloids are formed only in sclerotia which contain about $30 \%$ lipid and $0.01-0.10 \%$ alkaloids. Ergometrine is soluble in water but the so-called peptide alkaloids are soluble only in lipids.

The research on the production of alkaloids in saprophytic conditions took into account and tried to obtain cells in vitro with characteristics similar to those of sclerotia.

Under saprophytic conditions three phases of growth could be distinguished: colony growth on solid media which could be started from conidia, ascospore or sterile fragment of sclerotium growth of vegetative phase mycelium in liquid media. The last 
phase: the ergot alkaloid synthesis in higher amounts is obviously after about 14 days of cultivation in the production media and is accompanied by the typical differentiation of filamentous mycelium into sclerotial tissue like cells with high lipid content. Differentiation toward sclerotia-like cells can be achieved in different ways: using high concentrations of different substrates, after nutrient exhaustion, in presence of osmotic stabilizers or after $\mathrm{NaNO}_{3}$ addition. Besides specific morphological and ultrastructural differentiation, the essential biochemical features are crucial for alkaloid synthesis.

The majority of high-yielding strains were obtained by classical methods of mutation and selection performed either by UV and $\gamma$-irradiation or by a wide variety of chemical mutagens. Very successful programs were carried out in successive steps by using various mutagens. The protoplast fusion technique has begun to find useful applications either in producing improved mutant strains by intraspecies crosses or in formation of a novel spectrum of products by interspecies hybrids.<smiles>[R]C([R])[C@]1(NC(=O)[C@H]2C=C3c4cccc5[nH]cc(c45)C[C@H]3N(C)C2)O[C@]2(O)[C@@H]3CCCN3C(=O)[C@@H]([R3])N2C1=O</smiles>

Despite the fact that biosynthesis of ergot alkaloids is a genetically regulated process, genetic studies of the Claviceps fungi have received limited attention compared to genetic studies of other industrially important microorganisms. This is probably due to the complex life cycle of Claviceps species and their genetic structure, which makes manipulation difficult. 


\begin{tabular}{|c|c|c|c|c|}
\hline Name & $\mathrm{R}_{1}$ & $\mathrm{R}_{2}$ & $\mathrm{R}_{3}$ & Amino acid sequence of the tripeptide \\
\hline Ergotamine & $\mathrm{H}$ & $\mathrm{H}$ & & L-Proline-L-Alanine-L-Phenylalanine \\
\hline Ergosine & $\mathrm{H}$ & $\mathrm{H}$ & $\mathrm{CH}_{2} \mathrm{CH}\left(\mathrm{CH}_{3}\right)_{2}$ & L-Proline-L-Alanine-L-Leucine \\
\hline Ergocristine & $\mathrm{CH}_{3}$ & $\mathrm{CH}_{3}$ & & L-Proline-L-Valine-L-Phenylalanine \\
\hline$\alpha$-Ergokryptine & $\mathrm{CH}_{3}$ & $\mathrm{CH}_{3}$ & $\mathrm{CH}_{2} \mathrm{CH}\left(\mathrm{CH}_{3}\right)_{2}$ & L-Proline-L-Valine-L-Leucine \\
\hline$\beta$-Ergokryptine & $\mathrm{CH}_{3}$ & $\mathrm{CH}_{3}$ & $\mathrm{CH}\left(\mathrm{CH}_{3}\right) \mathrm{CH}_{2} \mathrm{CH}_{3}$ & L-Proline-L-Valine-L-Isoleucine \\
\hline Ergocornine & $\mathrm{CH}_{3}$ & $\mathrm{CH}_{3}$ & $\mathrm{CH}\left(\mathrm{CH}_{3}\right)_{2}$ & L-Proline-L-Valine-L-Valine \\
\hline Ergostine & $\mathrm{H}$ & $\mathrm{CH}_{3}$ & & $\begin{array}{l}\text { L-Proline-1- } \alpha \text {-aminobutyric acid-L- } \\
\text { Phenylalanine }\end{array}$ \\
\hline
\end{tabular}

\section{REFERENCES}

Jekkel,A., Kónya,A., Ilkôy,É., Boros,S., Horváth, Gy., Sütô,J.: Microbial conversion of Mevinolin. The Journal of Antibiotics (1997).

Kónya,A., Jekkel,A., Sütô,J., Salát,J.: Optimization of compactin fermentation. Journal of Industrial Microbiology and Biotechnology (1998).

Rehácek,Z., Sajdl,P. (eds): Ergot alkaloids. Academia-Praha. 1990. 